\title{
Ambities en werkelijkheid van New Public Management: De moeizame managementvernieuwingen bij lagere overheden in Nederland
}

\section{Henk ter Bogt}

SAMENVATTING Sinds 1985 traden bij Nederlandse gemeenten en provincies veel veranderingen op in onder meer de organisatiestructuur, het financieel en personeelsmanagement en de gehanteerde managementmethoden. Dit artikel gaat in op het 'waarom?' van deze veranderingen en op de effecten ervan. Op de achtergrond speelt de vraag of de veranderingen hoofdzakelijk werden doorgevoerd ter verhoging van de efficiëntie en effectiviteit, of dat het er tevens om ging 'met de trends mee te gaan'. Het praktijkonderzoek levert kennis op over de redenen voor en effecten van de 'vernieuwingen', wat ook van belang is voor organisaties die in de toekomst veranderingen willen doorvoeren.

1

\section{Inleiding}

Vanaf 1985 hebben gemeenten en provincies in Nederland allerlei ingrijpende organisatieveranderingen doorgevoerd. Veel van deze overheden kregen een gedecentraliseerde organisatiestructuur en de planning en control werd meer gericht op de producten, outputs, in plaats van op de middelen, inputs, en de processen. Deze veranderingen gingen vaak gepaard met initiatieven om de organisatiecultuur en houding van medewerkers meer extern te richten en te verzakelijken. Begrippen als bedrijfsmatig en klantvriendelijk hande-

Prof. dr. H.J. ter Bogt is bijzonder hoogleraar Overheidsmanagement en universitair hoofddocent Management accounting aan de Faculteit der Economische Wetenschappen van de Rijksuniversiteit Groningen. len werden geïntroduceerd. De 'vernieuwingen' kregen bij Nederlandse gemeenten en provincies vooral vorm via het zogenaamde BBI-project (project Beleids- en BeheersInstrumentarium). ${ }^{1}$ Het BBI-project kwam nauw overeen met wat internationaal wordt aangeduid als New Public Management (NPM).

In de ruim twintig jaren die inmiddels sinds 1985 zijn verstreken, hebben lagere overheden - en vooral ook gemeenten en provincies, waar dit artikel zich verder op richt - vele verdere vernieuwingen doorgevoerd in de in hun organisatie gehanteerde managementinstrumenten (zie ook Martens et al., 2002). In dit artikel komt de vraag aan de orde wat de redenen waren voor de diverse managementvernieuwingen en wat de effecten ervan zijn. In dit verband wordt ook ingegaan op de vraag in hoeverre de ambities van NPM en het BBI-project inmiddels zijn gerealiseerd. Het praktijkdeel van het artikel steunt grotendeels op onderzoek dat in 2004 en 2005 is gedaan bij twaalf gemeenten en twee provincies (zie Ter Bogt, 2005b). ${ }^{2}$

Het verrichte praktijkonderzoek en dit artikel zijn in de eerste plaats van belang om na circa twintig jaren eens een overzicht te krijgen van de redenen voor en resultaten van de vele managementvernieuwingen die lagere overheden doorvoerden. Kennis hierover kan zinvol zijn als er ideeën leven voor verdere vernieuwingen in overheids- en andere non-profitorganisaties. Het artikel beoogt een algemeen beeld te geven van de hoofdlijnen van de onderzoeksuitkomsten.

De verdere opbouw van het artikel is als volgt. In paragraaf 2 worden de onderzoeksvragen geformuleerd op basis van een schets van de inhoud en ambities van BBI en NPM en literatuur op het gebied van het (sociologisch) institutionalisme. In paragraaf 3 
volgt een kort overzicht van de uitkomsten van eerder onderzoek, vooral op het gebied van de planning en control. In paragraaf 4 wordt de voor het praktijkonderzoek gevolgde werkwijze toegelicht, waarna in paragraaf 5 diverse uitkomsten van het praktijkonderzoek worden gepresenteerd. Tot slot volgen in paragraaf 6 een samenvatting en enkele conclusies.

\section{Managementvernieuwingen: gericht op efficiëntie en effectiviteit?}

Het BBI-project begon in 1987 en daarmee lag de start vóór het tijdstip waarop het begrip New Public Management in zwang kwam. ${ }^{3}$ De ambities van het BBI-project waren groot. In een afsluitend rapport werd aangegeven dat BBI beoogde een samenhangende visie aan te reiken met als hoofddoel de ook op lokaal niveau gegroeide kloof tussen overheid en burger te overbruggen (Houwaart, 1995, pp. 15, 45). Die kloof zou zijn ontstaan ten gevolgde van de ingewikkelder geworden bestuurlijk-politieke agenda, de professionalisering van de politiek en het zwaardere stempel dat wetenschap en techniek drukken op het overheidshandelen. BBI kende de drie onderstaande basisbeginselen (Houwaart 1995, p. 15; zie ook Van Helden en Bonhof, 1995, p. 8).

- Versterking van de positie van de gemeenteraad. Dit zou gerealiseerd moeten worden door informatie op maat te bieden, de afwegingsfunctie van het beleidsinstrumentarium te verbeteren en het inzicht in de gevolgen en doeltreffendheid van het beleid te verhogen.

- Betere beheersing van de organisatie. Hiertoe waren onder meer van belang de introductie van integraal management, verbetering van de doelmatigheid van de beleidsuitvoering, sturing op output, de ontwikkeling van kengetallen en kwaliteitseisen, een zakelijker bedrijfscultuur en de waarborging van een goede kwaliteit van de arbeid en arbeidsomstandigheden. ${ }^{4}$

- Toename van de klantgerichtheid. Dit zou tot stand moeten komen door vergroting van de flexibiliteit van de organisatie, grotere aandacht voor afnemerswensen en klantvriendelijkheid, en het zo laag mogelijk in de organisatie leggen van verantwoordelijkheden.

In de praktijk lag het accent van BBI sterk op de introductie van een gedecentraliseerde organisatiestructuur ('productverantwoordelijke eenheden') en vooral op de ontwikkeling van de productbegroting, met daaraan gekoppelde tussentijdse rapportages, en een productjaarrekening (Houwaart, 1995, p. 12; Van Helden, 1998, p. 20). In een productbegroting staan in principe niet alleen de voor bepaalde activiteiten beschikbare middelen vermeld, maar ook de ermee te realiseren prestaties (zoals de hoeveelheden 'product', de kostprijs en kwaliteit van producten, of de aantallen van bepaalde essentiële activiteiten). Het begroten en tussentijds rapporteren over de prestaties aan de leden van gemeenteraad/provinciale staten en College van Burgemeester en Wethouders/Gedeputeerde Staten, werden van belang geacht om hen te voorzien van gegevens waardoor de control van de organisatie en besluitvorming over beleid konden plaatsvinden op basis van informatie over concrete prestatievoornemens en -realisatie. Ook voor ambtenaren zou deze informatie nuttig zijn bij hun takuitoefening. Bovendien zouden de prestatiegegevens van belang zijn om burgers beter te informeren over de prestaties van gemeente/provincie. $\mathrm{Al}$ waren de formele doelstellingen breder, in de praktijk van BBI speelden rationalisatie van de bedrijfsvoering en verhoging van de economische efficiëntie en effectiviteit een hoofdrol.

Volgens Hood (1995, p. 94) zijn de twee belangrijkste uitgangspunten van New Public Management het verkleinen van de verschillen tussen de publieke en private sector en het verleggen van de nadruk van verantwoording van processen naar verantwoording van resultaten. BBI heeft sterke overeenkomsten met NPM (zie Hood, 1991, 1995). NPM betekent, kort gezegd, dat overheidsorganisaties werken met bedrijfsmatige instrumenten en managementstijlen. Sinds de introductie van BBI en NPM zijn allerlei managementveranderingen gestart die in het verlengde ervan liggen, bijvoorbeeld op het gebied van informatie- of personeelsmanagement. Zonder hier gedetailleerd in te gaan op de door Hood geschetste algemene kenmerken van NPM en van land tot land optredende verschillen, mag worden gesteld dat ook NPM zich vooral richt op een meer zakelijk-rationele bedrijfsvoering. De uitgangspunten en vooral de praktijk van BBI en NPM, zijn dus sterk gericht op verhoging van de (economische) efficiëntie en effectiviteit van overheidsorganisaties. ${ }^{5}$

Er zijn ook auteurs die stellen dat organisaties die de bedrijfsvoering vernieuwen zich sterk laten leiden door andere overwegingen dan verhoging van economische efficiëntie en effectiviteit. Veel sociologisch-institutionele auteurs stellen bijvoorbeeld dat economisch-rationele overwegingen het gedrag van organisaties niet goed verklaren. Zij richten zich voor de verklaring van organisatieveranderingen sterk op sociale en culturele aspecten, zoals de regels en gebruiken in een samenleving.

DiMaggio en Powell (1983, pp. 149-150) signaleren bijvoorbeeld bepaalde trends in organisatieveranderingen en zoeken een verklaring voor de onderlinge navolging 
die zij dikwijls zien optreden en voor de gelijkvormigheid die hierdoor ontstaat tussen organisaties. Het streven naar efficiëntieverhoging biedt naar hun oordeel niet altijd een verklaring voor deze veranderingen (DiMaggio en Powell, 1983, pp. 147, 157). Meyer en Rowan (1977) vragen zich af of organisaties soms misschien slechts 'rituele' veranderingen doorvoeren om naar buiten toe de indruk te wekken dat de organisatie is veranderd, terwijl dat in werkelijkheid nauwelijks het geval is. Door dergelijke ogenschijnlijke veranderingen kan een organisatie proberen 'externe legitimiteit' te verwerven - dat wil zeggen 'acceptabel' zijn voor de omgeving en daarmee oppositie of kritische vragen vermijden - en zo 'sociaal-rationeel' te handelen (Meyer en Rowan, 1977, pp. 352, 356-359; zie ook Ter Bogt, 2005a, p. 62). Sommige onderzoekers op het gebied van NPM zoeken de verklaring voor de organisatieveranderingen bij overheden ook in sterke mate in aspecten als navolging en externe legitimatie (zie bijvoorbeeld Seal, 1999, pp. 310, 320-324; English et al., 2005, pp. 48-49).

Het is echter de vraag of het willen volgen van elders geïntroduceerde veranderingen zonder meer op gespannen voet staat met het streven naar hogere economische efficiëntie en effectiviteit. In de praktijk van gemeenten en provincies zouden beide overwegingen een rol gespeeld kunnen hebben. Het voorgaande leidt tot de drie navolgende onderzoeksvragen.

1 Wat is de invloed geweest van de diverse managementveranderingen op de economische efficiëntie en effectiviteit van de onderzochte gemeenten en provincies?

2 In hoeverre speelde het streven naar verhoging van de economische efficiëntie en effectiviteit een rol bij de introductie van BBI- en NPM-gerelateerde managementveranderingen in de onderzochte gemeenten en provincies?

3 In hoeverre speelden overwegingen van navolging van trends en externe legitimatie een rol bij de introductie van BBI- en NPM-gerelateerde managementveranderingen in de onderzochte gemeenten en provincies? In paragraaf 5 van dit artikel komen de in de praktijk bij diverse gemeenten en provincies doorgevoerde managementveranderingen aan de orde, alsmede de redenen ervoor en de effecten ervan. Op die manier wordt informatie aangedragen met betrekking tot de drie onderzoeksvragen. Vervolgens worden op basis hiervan in paragraaf 6 conclusies geformuleerd omtrent elk van de onderzoeksvragen.

\section{Eerder onderzoek naar de effecten van veranderingen in de planning en control}

$\mathrm{Al}$ ontbreekt een algemeen beeld, in Nederland is wel allerlei onderzoek gedaan naar de in het kader van BBI en NPM doorgevoerde veranderingen bij gemeenten en provincies. Zonder hier alle nuances te kunnen weergeven, komt daaruit naar voren dat rond het jaar 2000 het overgrote deel van de gemeenten en alle provincies een decentrale organisatiestructuur en de productbegroting hadden ingevoerd (Moret/A+O-fonds Gemeenten, 1997, pp. 18-19 en 31-32; Van Helden, 1999, p. 248). In het kader van de in 2002/2003 ingevoerde Wet dualisering gemeentebestuur/provinciebestuur en de daarin voorgeschreven programmabegroting, is de met de productbegroting vergelijkbare 'productenraming' inmiddels een verplicht onderdeel van de gemeentelijke en provinciale planning en control. Verder hebben veel gemeenten en provincies in de afgelopen jaren bijvoorbeeld ook de ICT versterkt en is aandacht besteed aan de organisatiecultuur en kwaliteitsmanagement.

Voorzover het gaat om de planning en control, komt uit het eerder verrichte onderzoek het beeld naar voren dat de outputgerichtheid en kwaliteit van de prestatiegegevens in gemeenten en provincies vaak matig zijn en dat er niet veel gebruik van wordt gemaakt (zie bijvoorbeeld Van Helden, 1998; Bordewijk en Klaassen, 2000; Aardema, 2002, pp. 315-320). Van Helden en Johnsen (2002) concluderen dat de vermelde prestaties veelal ook nauwelijks beheersbaar zijn voor de betrokken overheden. Verder maken managers en bestuurders bij hun dagelijkse werkzaamheden dikwijls maar (zeer) matig gebruik van de beschikbare prestatiegegevens (Jansen, 2000, pp. 130-137; Ter Bogt, 2004). Bordewijk en Klaassen (2000, p. 94) stellen dat de werkelijke planning en control nog grotendeels is gebaseerd op financiële budgetten, dus op de inputs.

Een compleet overzicht ontbreekt. Veel van het beschikbare onderzoek is echter kritisch en stelt dat de geïntroduceerde instrumenten misschien de indruk wekken van meer zakelijkheid en bedrijfsmatigheid, maar dat dit beeld niet erg terecht is.

\section{Opzet van het empirisch onderzoek}

Als de in het kader van BBI en NPM ingevoerde managementvernieuwingen dikwijls slechts beperkte effecten hebben, is het de vraag waarom gemeenten en provincies toch in hoog tempo vernieuwingen blijven invoeren. Deze vraag komt temeer op omdat in de literatuur soms wordt gesteld dat een goede introductie van ingrijpende accounting- en controlveranderingen wel tot circa vijf jaren kan vergen (zie bijvoorbeeld Shields en Young, 1989).

Om een nader beeld te krijgen van onder meer de aard, achtergrond en effecten van de (voortgaande) vernieuwingen, werd besloten tot een beschrijvend en verkennend onderzoek. Het empirisch onderzoek richtte zich 


\section{Bijlage A De opzet en inhoud van de interviews}

De geïnterviewden ontvingen voorafgaand aan het interview een korte notitie waarin het onderzoek werd toegelicht. Tijdens de interviews kwamen met name vragen uit een tevoren opgestelde lijst van open vragen aan de orde. Soms werden niet alle vragen uit deze lijst gesteld (bijvoorbeeld omdat de geïnterviewde er zelf in een eerder gegeven antwoord al op inging, of omdat een geïnterviewde al aangaf er geen kennis over te hebben). Daarnaast werden dikwijls ad hoc aanvullende vragen toegevoegd, bijvoorbeeld om nadere duidelijkheid te krijgen over het oordeel van de geïnterviewde. Om een beeld te geven van de aard van de gestelde vragen, voorzover voor dit artikel relevant, worden onderstaand diverse van de tevoren ontwikkelde vragen vermeld.

- Welke belangrijke managementveranderingen - veranderingen in de organisatiestructuur, planning en control en meer in het algemeen de wijze van sturing - zijn de afgelopen circa vijftien à twintig jaren doorgevoerd in uw organisatie?

- Wat werd er, voorzover u bekend, verwacht van elk van deze veranderingen? Welke doelen werden ermee nagestreefd?

- Welke factoren en/of overwegingen, of misschien personen of instanties, speelden een rol bij de beslissing om elk van de vernieuwingen door te voeren?

- Kunt u iets zeggen over de effecten die elk van deze veranderingen heeft gehad, bijvoorbeeld op de efficiëntie of de effectiviteit van de organisatie, of de 'klantgerichtheid'? Is er evaluatie-onderzoek gedaan naar het effect van de diverse doorgevoerde veranderingen?

- Is er (ook) onderzoek gedaan onder burgers, bijvoorbeeld omnibusonderzoek, om hun oordelen over de gemeentelijke dienstverlening te peilen? Zo ja, zijn uitkomsten hiervan beschikbaar voor mijn onderzoek?

- Kent u voorbeelden van veranderingen in het instrumentarium of de wijze van sturing die niet succesvol zijn geweest?

- Welke factoren hebben naar uw oordeel (mede) bepaald of een bepaalde vernieuwing al dan niet succes opleverde?

De aard van de vragen bood de geïnterviewden de mogelijkheid hun antwoorden naar eigen inzicht 'in te kleuren' en er de nuances bij aan te brengen die zij nodig achtten. Dat leidde tot rijk geschakeerde antwoorden, die zich achteraf moeilijk laten reduceren tot eenvoudige antwoordcategorieën als 'zeer sterk enigszins - geheel niet'. Dat is ook niet nodig, omdat het hier niet ging om een schriftelijke enquête die op statistische wijze wordt verwerkt en representativiteit beoogt, maar om een beschrijvend en verkennend onderzoek dat erop is gericht eerst eens een diepgaand beeld te verkrijgen van de oordelen van de geïnterviewde personen en de achtergronden erbij. In de interviewverslagen waarop dit artikel mede is gebaseerd, is ook zoveel mogelijk rekening gehouden met de diverse nuanceringen die de geïnterviewde in zijn/haar antwoord naar voren bracht.

niet op het opsporen van eventuele verschillen tussen overheden of personen met uiteenlopende verantwoordelijkheden, maar op het verkrijgen van een algemeen beeld van de oordelen van betrokkenen.

De in dit verkennende onderzoek betrokken personen, gemeenten en provincies zijn niet geselecteerd om te komen tot een 'representatieve' afspiegeling (zie ook Scapens, 2004, p. 260). De uitkomsten kunnen echter wel een beeld geven van de in de praktijk gevolgde werkwijzes en de overwegingen en eventuele problemen daarbij. De geïnterviewden zijn, mede in overleg met twee contactpersonen, benaderd op basis van spreiding over gemeenten en provincies, geografische spreiding, de gemeente-omvang en hun werkterrein/beleidsportefeuille (zie ook Ter Bogt, 2005b, pp. 37 en 73-74). Omdat eerder onderzoek aangaf dat kleine gemeenten minder actief waren in het doorvoeren van managementvernieuwingen, vond daar geen onderzoek plaats (zie Moret/A+O fonds Gemeenten, 1997).
In 2004 en 2005 werden 23 interviews gehouden met bestuurders en ambtelijk managers in gemeenten en provincies. Aan de hand van open vragen die werden ontwikkeld op basis van literatuur over economische efficiëntie en effectiviteit en de sociologische institutionele theorie, werd in de gedeeltelijk gestructureerde interviews intensief ingegaan op onder meer de redenen voor de invoering van de diverse managementvernieuwingen en de effecten ervan (zie ook bijlage A). Van de interviews werd een uitgebreid schriftelijk verslag opgesteld, dat ter becommentariëring werd voorgelegd aan de geïnterviewde. De definitieve verslagen zijn gebruikt voor dit artikel.

Om een nader beeld te krijgen van de eventuele effecten van vernieuwingen, werd ook informatie gebruikt die beschikbaar is over de tevredenheid van burgers over hun woonomgeving en de kwaliteit van de overheidsdienstverlening. Vooral grotere gemeenten verzamelen hierover gegevens via monitor- en omnibusonderzoek en benchmarkstudies. ${ }^{6}$ 


\section{- Vernieuwingen en effecten ervan in de praktijk}

De eerder in dit artikel besproken onderzoeksresultaten hadden hoofdzakelijk betrekking op veranderingen in de planning en control, zoals de introductie van productbegrotingen. In de 23 interviews werden de veranderingen in de planning en control besproken in combinatie met andere managementveranderingen. Onderstaand komen enkele belangrijke uitkomsten van de interviews aan de orde (zie ook Ter Bogt, 2005b, pp. 37-53). De hier gerapporteerde uitkomsten hebben betrekking op onder meer de aard van de vernieuwingen, de redenen ervoor en de effecten ervan. Op deze wijze is informatie verzameld omtrent de aspecten die aan de orde komen in de drie onderzoeksvragen.

\subsection{Doelen van en redenen voor de managementver- nieuwingen}

Al waren er op details verschillen, uit de interviews kwam naar voren dat de organisaties sterk overeenkomstige doelen nastreefden met de diverse managementveranderingen. Overwegingen die als 'functioneel-zakelijk' zijn te beschouwen waren belangrijk, zoals de wens efficiënter, bedrijfsmatiger en klantgerichter te werken, of de externe oriëntatie, transparantie, kwaliteit en flexibiliteit van de organisatie en de medewerkers te versterken. Daarnaast speelden ook navolging, meegaan met trends en het leren van andere organisaties een wezenlijke rol. ${ }^{7}$

Veel geïnterviewden waren (zeer) kritisch over de vele vernieuwingen en de voorbereiding en effecten ervan. Soms, aldus een geïnterviewde, gaan 'enkele specialisten met een bepaalde vernieuwing op de loop ... terwijl eigenlijk niet duidelijk is of er wel echt behoefte [aan] bestaat .... In andere gevallen werden eenvoudigweg elders gestarte veranderingen nagevolgd, mede uit vrees anders door collega-bestuurders en -managers, of door burgers en pers, te worden beschouwd als achterblijver.' 'Organisaties imiteren andere organisaties die zoiets hebben ingevoerd, dat is bij gemeenten niet anders dan elders', aldus een ambtenaar.

Op hoofdlijnen waren de met de veranderingen nagestreefde doelen vrij duidelijk, maar ze werden tevoren niet altijd grondig uitgewerkt. De specifieke doelen van elk van de afzonderlijke projecten en de plaats ervan in het grotere geheel, waren regelmatig onduidelijk. Evenmin waren de plannen en het implementatietraject altijd goed voorbereid en soms waren tijdens de uitvoering ingrijpende veranderingen en nadere uitwerkingen nodig.
Volgens veel van de 23 geïnterviewden lag het tempo van de managementveranderingen in de afgelopen jaren erg hoog. $\mathrm{Zij}$ vonden het echter veelal lastig de precieze redenen voor het hoge veranderingstempo aan te geven. In algemene zin werd gewezen op regelgeving en (nieuwe) bezuinigingen van de rijksoverheid en vooral ook op het toegenomen veranderingstempo in de samenleving. De volgens de geïnterviewden meer dynamische en veeleisende en soms grillige omgeving waarin overheidsorganisaties werken, leidt volgens hen tot de noodzaak van veranderingen en goede prestaties om zo voldoende vertrouwen te houden van de burgers.

Tijdens de interviews werden ook allerlei meer specifieke externe en interne ontwikkelingen en factoren genoemd die leidden tot druk om de organisatie en de bedrijfsvoering te veranderen. Daarbij kwamen factoren naar voren als de adviezen van accountants en externe adviseurs, de gevoelde noodzaak om 'bij de tijd' te zijn, de trend tot verzakelijking en 'verjuridicering' in de samenleving, het hogere opleidingsniveau en de grotere mondigheid van burgers, de toenemende financiële risico's vanwege samenwerkingsprojecten en door het rijk overgedragen beleidstaken, en de toegenomen omvang en deskundigheid van externe gesprekspartners (waardoor ook de deskundigheid en zakelijkheid van ambtenaren diende toe te nemen). Verder werd vooral gewezen op de grote onzekerheid onder bestuurders en managers vanwege de in de laatste jaren relatief grote fluctuaties in politieke voorkeuren van de kiezers en de kritische houding van burgers en media ten opzichte van de overheid. Hierdoor is het 'politieke ongeduld' toegenomen, wat betekent dat de interesse in veranderingen die niet op korte termijn resultaat opleveren snel verdwijnt, zo werd gesteld. Door dergelijke ontwikkelingen voelen bestuurders en managers meer noodzaak tot veranderingen die ertoe zouden kunnen leiden dat burgers en andere belanghebbenden beter en efficiënter worden bediend.

Samengevat, lijkt het erop dat er enerzijds diverse invloeden en ontwikkelingen waren waardoor politieke bestuurders en ambtelijk managers druk voelden om de prestaties van hun organisatie te verbeteren en zij er werkelijk naar streefden de economische efficiëntie en effectiviteit te verhogen. Anderzijds kwam duidelijk naar voren dat ook vaak de wens of noodzaak werd gevoeld om de organisatie 'op uiterlijkheden' modern te laten ogen, waardoor diverse veranderingen slechts oppervlakkig of onvolledig werden doorgevoerd. 


\subsection{Aard van de managementvernieuwingen}

Verschillende bestuurders en managers stelden dat er in de loop der jaren een accentverschuiving optrad in de managementveranderingen. Aanvankelijk lag de nadruk sterk op veranderingen in de organisatiestructuur (decentralisatie, 'verplatting' van organisaties) en vanaf circa 1990 op de prestatiegerichte planning en control, vooral vanwege BBI. Dikwijls werd gesteld dat dergelijke veranderingen nogal 'instrumenteel' zijn en vrij weinig betekenis hebben voor het functioneren van de organisatie en de medewerkers. 'Je bent er niet met, wat ik maar zal noemen, alleen de technische dingen', zo constateerde een ambtenaar.

Veel geïnterviewden wezen op de accentverschuiving sinds circa 1998. Kwaliteitsbeleid en 'brede organisatieontwikkeling', en vooral ook de vaardigheden en 'houding' van de medewerkers, staan nu volop in de belangstelling. Een geïnterviewde bij een provincie constateerde dat het veranderingstraject waaraan inmiddels meer dan vijftien jaar met vallen en opstaan werd gewerkt, langzamerhand vrucht afwierp. Vooral door de intensieve inzet van kwaliteits- en personeelsmanagement begon de resultaatgerichtheid van verscheidene medewerkers geleidelijk aan echt te veranderen.

Overigens gaven verscheidene geïnterviewden aan dat nieuwe, algemeen doorgevoerde en ingrijpende veranderingen van de organisatiestructuur niet wenselijk werden gevonden. Een algemene wijziging van de organisatiestructuur zou 'alweer afbreken wat er net aan goeds is opgebouwd' en weer veel tijd en 'intern gerichte energie' vergen.

\subsection{Prestatiegerichtheid}

Diverse van de in gemeenten en provincies ingevoerde BBI- en NPM-achtige instrumenten werden niet of slechts in beperkte mate als een succes gezien. De meting van de productie en vooral de effecten van beleid werd gezien als moeizaam, ondanks bijvoorbeeld de stappen die werden gezet via de programmabegroting en de verplichte rapportages van gemeenten aan de rijksoverheid in het kader van het Grote Stedenbeleid. Benchmarking werd soms moeizaam gevonden vanwege onvoldoende vergelijkbare prestatiegegevens. Desondanks gaven de geïnterviewden vrij algemeen aan dat hun organisatie veel aandacht schonk aan het leveren van betere prestaties. ${ }^{8}$ Er werden diverse middelen ingezet om de nadruk op goede prestaties en resultaatgerichtheid te onderstrepen. Via verantwoordings- en functioneringsgesprekken en Persoonlijke Ontwikkelingsplannen werd aandacht besteed aan de prestaties en verdere ontwikkeling en vaardigheden van medewerkers op de diverse niveaus. Zowel ambtelijk managers als hun ondergeschikten, konden zich op het punt van de resultaatgerichtheid geen vrijblijvende houding meer permitteren, zo werd regelmatig gesteld. Diverse gemeenten en provincies hebben inmiddels een beleid ontwikkeld, of ontwikkelen dit, waardoor managers salarisverhogingen en andere (financiële) beloningen kunnen koppelen aan hun oordeel over de prestaties van medewerkers. Weliswaar is het variabele beloningsdeel in het algemeen relatief beperkt, maar de gecreëerde mogelijkheid voor prestatiegerelateerde beloning werd toch gezien als een zinvol middel om prestaties te stimuleren. Ook vanwege het prestatiegerichte personeelsmanagement werden betere kwalitatieve, maar zeker ook kwantitatieve prestatiegegevens noodzakelijk gevonden, om te vermijden dat subjectieve indrukken van managers een te grote rol spelen bij de beoordeling van medewerkers.

De precieze uitwerking varieerde, maar al met al stelden veel geïnterviewden dat in de afgelopen jaren een forse verzakelijking plaatsvond in de interne cultuur en het personeelsmanagement. Dat betekent bijvoorbeeld dat er een zwaarder accent kwam te liggen op het duidelijk benoemen van (gewenste en aanwezige) capaciteiten van medewerkers, (te realiseren en gerealiseerde) prestaties, een 'klantgerichte' houding en het nakomen van interne en externe afspraken en toezeggingen ('afspraak=afspraak'). Er werd meer gewerkt met resultaatgerichte afspraken en het personeelsmanagement werd nadrukkelijk ook ingezet om het prestatieniveau van de organisatie te verhogen.

\subsection{Effecten van de managementvernieuwingen}

De toegenomen aandacht voor prestaties betekent niet dat ook veel prestatiegegevens beschikbaar zijn. Een goede beoordeling van de effecten van de managementvernieuwingen is moeilijk, aldus bijna alle geïnterviewden, omdat de efficiëntie en effectiviteit van de organisatie en de effecten van veranderingen niet op systematische en enigszins integrale wijze worden onderzocht. De moeilijke meetbaarheid van veel overheidsprestaties speelde daarbij een rol. Daarnaast bestond er niet altijd behoefte de vernieuwingen achteraf systematisch en kritisch te beoordelen. 'We kijken vaak meer naar voren dan terug, aldus een geïnterviewde. Sommige geïnterviewden stelden overigens dat dit laatste kan veranderen door de activiteiten van een gemeentelijke of provinciale Rekenkamer(-commissie), die vanaf 2006 verplicht is en waarmee veel lagere overheden inmiddels al zijn gestart.

$\mathrm{Al}$ was het moeilijk te oordelen over de effecten, er werden weinig managementveranderingen gesigna- 
leerd die echt negatieve effecten hadden op het functioneren van de organisatie. In verscheidene gevallen was de 'indruk' dat de veranderingen per saldo (licht) positief hadden bijgedragen aan zaken als het financieel beheer en de efficiëntie, effectiviteit en klantgerichtheid. ${ }^{9}$ Daarbij moet erop worden gewezen dat de mate waarin het oordeel positief was, vrij sterk varieerde.

Enkele geïnterviewden stelden dat eigenlijk sprake is van een langdurig veranderingsproces, waarin 'al zoekende' steeds nieuwe stappen worden gezet, waardoor het moeilijk is de effecten van elke afzonderlijke vernieuwing te beoordelen. Voorzover toch meningen werden gegeven over de effecten van afzonderlijke veranderingen, verschilden deze enigszins. Veranderingen als de toegenomen rol van ICT, de versterking van het financieel beheer, de vergroting van de resultaat- en externe gerichtheid en de verhoging van de kwaliteit van ambtenaren, werden echter door diverse geïnterviewden als tamelijk succesvol gezien.

$\mathrm{Al}$ waren er enkele waarderende geluiden, de oordelen over het BBI-project waren per saldo vrij negatief. Enkele geïnterviewden constateerden vooral positieve 'cultuureffecten' van het project. 'Hierdoor werd veel meer gedacht over het definiëren van taken en heldere verantwoordingsstructuren. Het denken in termen van producten kwam hierdoor op, er kwam een nuttige verzakelijking ..., aldus een geïnterviewde. Hij gaf daarnaast echter aan dat hij betwijfelde of de productbegrotingen en de wijze waarop ze gestalte kregen, succesvolle onderdelen waren van BBI. Daarnaast gaven verschillende geïnterviewden ronduit negatieve oordelen over de productbegrotingen en de ermee verbonden rapportages, die een van hen bondig samenvatte met de woorden: '...waardeloos [terwijl] ... ook niemand er iets mee doet.'

Voor het onderzoek stelden de onderzochte organisaties verscheidene rapportages van omnibus-, monitoren benchmarkonderzoek beschikbaar. Via omnibusen monitoronderzoek, en soms ook via burgerpanels, worden op systematische wijze de oordelen van burgers gemeten over bijvoorbeeld hun woonomgeving, beleidskwesties en de kwaliteit van de gemeentelijke of provinciale dienstverlening. Dat levert veel informatie op, die ook van belang is voor (de bijsturing van) het beleid, aldus geïnterviewden. Dergelijke onderzoeken geven echter evenmin een duidelijk en compleet beeld van de overheidsprestaties en de effecten van managementveranderingen. Dat geldt ook voor benchmarkonderzoeken. Dit neemt niet weg dat uit de beschikbare rapporten het beeld naar voren komt dat veel burgers gematigd of (heel) redelijk tevreden zijn over uiteenlopende aspecten van hun stad/buurt, allerlei concrete dienstverlening van de betrokken overheden en de wijze waarop deze zich kwijten van uitvoerende taken. Het algemene beeld van veel burgers over 'de overheid' mag de laatste jaren negatief zijn (Becker en Dekker, 2005, p. 344), dat ligt klaarblijkelijk iets anders als het gaat om concrete zaken, zoals de wijze waarop men is geholpen aan de balie, de kwaliteit van de informatie, het onderhoud van wegen en parken, of de tevredenheid met de woonomgeving. ${ }^{10}$

De rapporten maken het niet mogelijk goed te oordelen over de effecten van de veranderingen. Dat is temeer het geval omdat dikwijls nog maar voor een korte periode gegevens beschikbaar zijn. Verder zijn verscheidene van de vermelde uitkomsten niet uitsluitend het gevolg van gemeentelijk of provinciaal beleid. Het is echter wel duidelijk dat de voor verschillende jaren beschikbare 'scores' meestal vrij stabiel zijn, dat de uitkomsten soms verbeteren en dat er weinig verslechteringen zichtbaar zijn (zie ook Ter Bogt, 2005b, pp. 75-80).

Er valt op basis van de onderzoeksgegevens dus geen goed onderbouwd oordeel te geven over de effecten van de managementveranderingen. Afgaande op de indrukken uit de interviews en de wel beschikbare gegevens uit de rapporten, komt al met al echter het beeld naar voren dat alle veranderingen samen een (licht) positieve invloed hebben gehad op het functioneren en de klantgerichtheid van de betrokken gemeenten en provincies.

\section{Samenvatting en conclusies}

In de interviews met 23 bestuurders en managers in gemeenten en provincies kwam naar voren dat velen van hen kritisch waren over diverse aspecten van de managementvernieuwingen, waarmee hun organisaties aansloten bij het Nederlandse BBI-project en de opkomst van NPM. De doelen van de doorgevoerde veranderingen waren soms onduidelijk, of de veranderingen waren onvoldoende voorbereid en volgden elkaar te snel op, terwijl de effecten ervan moeilijk zijn te bepalen. Enigszins complete gegevens over de effecten en meer in het algemeen de prestaties en efficiëntie en effectiviteit van de betrokken organisaties ontbreken. Veel geïnterviewden hadden echter de indruk dat de diverse vernieuwingen per saldo een (licht) positief effect hadden op het functioneren van hun organisatie. Ook de gegevens in de beschikbare omnibus-, monitor- en benchmarkonderzoeken zijn onvolledig, zeker als het gaat om de effecten van managementveranderingen. Echter, voorzover dergelijke rapporten gegevens bevatten over concrete prestaties van gemeenten 
en provincies en de tevredenheid van burgers erover, is het beeld dat eruit naar voren komt veelal gematigd tot vrij positief en stabiel.

Er zijn hier geen goed onderbouwde conclusies te trekken, omdat in de onderzochte organisaties enigszins toereikende gegevens over de overheidsprestaties en de effecten van beleid ontbreken. Met erkenning van de problemen rond de meting van overheidsprestaties, kan het verzamelen van betere prestatiegegevens - zonder dat mag worden verwacht dat deze altijd compleet en 'hard' zijn en een simpele basis bieden voor 'afrekening' - dan ook worden gezien als een punt dat de aandacht van gemeenten en provincies blijft verdienen.

Voorzover uit de nu beschikbare onderzoeksgegevens toch een beeld is te destilleren, hadden de diverse managementveranderingen samen een licht positieve invloed op het functioneren van de betrokken gemeenten en provincies (zie onderzoeksvraag 1). Burgers en andere belanghebbenden worden waarschijnlijk beter geholpen dan voorheen en in die zin kan de effectiviteit zijn toegenomen. Over de efficiëntie waarmee dit gebeurt, valt nauwelijks te oordelen, omdat daarvoor gegevens beschikbaar moeten zijn over de voor de activiteiten en producten ingezette middelen. Algemene cijfers over het tussen 1996 en 2003 gegroeide aantal ambtenaren bij gemeenten en provincies zeggen weinig, omdat die mede een gevolg zijn van bijvoorbeeld veranderingen in takenpakketten (zie ook Ministerie van BZK, 2004).

Samengevat, kwam uit de interviews het beeld naar voren dat de managementvernieuwingen enerzijds voortvloeien uit trends, navolging, adviezen van externe deskundigen en het leren van andere organisaties. Dergelijke factoren sluiten aan bij de denkbeelden van de sociologische institutionelen (zie onderzoeksvraag 3). Anderzijds speelden zaken als verhoging van efficiëntie, effectiviteit, klantgerichtheid en transparantie een rol. Functioneel-economische overwegingen, waarop het BBI-project en NPM de nadruk leggen, hebben dus waarschijnlijk ook een belangrijke rol gespeeld (onderzoeksvraag 2). De ambities van het BBI-project (en NPM) zijn lang niet volledig gerealiseerd. Dat betekent echter volgens betrokkenen niet dat geen enkele positieve verandering optrad in het functioneren en de dienstverlening van hun organisatie. Het is in dit verband misschien ook zinvol te wijzen op de constatering van Scapens (1994, p. 303) dat een te sterke gerichtheid op het 'ideaalbeeld' ertoe kan leiden dat het zicht verloren gaat op wat er in de praktijk in organisaties wel is veranderd. Juist dit laatste is van belang om een beeld te krijgen van de effecten van vernieuwingen.
Vooral via instrumenten op het gebied van personeelsmanagement is de laatste jaren nadruk gelegd op de vergroting van de vaardigheden en resultaatgerichtheid van medewerkers. Veel geïnterviewden vonden een (verdere) versterking van de zakelijkheid, dienstverlening, transparantie, efficiëntie en effectiviteit temeer noodzakelijk vanwege de in recente jaren vrij instabiele politieke voorkeuren van kiezers en de meer kritische houding van mondige en goed opgeleide burgers ten aanzien van de overheid. Bovendien werden gemeenten en provincies in de afgelopen jaren weer geconfronteerd met bezuinigingen. Dergelijke ontwikkelingen kunnen ertoe geleid hebben dat voor veel politieke bestuurders - die uiteindelijk geacht worden de koers van overheidsorganisaties te bepalen - het economisch rationeel handelen sterker is gaan samenvallen met sociaal-rationeel en 'politiekrationeel' handelen. Dat wil zeggen: om de steun van kiezers te behouden en te vergroten, benadrukken politici onder meer de noodzaak van vergroting van de 'externe legitimiteit' van het overheidshandelen en daarvoor is het ook van belang dat overheidsorganisaties in vele opzichten goed functioneren (of tenminste 'een goede indruk' maken). Zo bezien, kan een combinatie van economisch- en sociaal-rationele overwegingen dus een rol hebben gespeeld bij de doorgevoerde managementvernieuwingen. Toekomstig onderzoek op grotere schaal kan misschien uitwijzen in hoeverre een combinatie van dergelijke overwegingen daadwerkelijk bijdraagt aan het verklaren van managementveranderingen in de publieke en wellicht ook in de profitsector.

\section{Literatuur}

Aardema, H., (2002), Doorwerking van BBI, Bestuur \& Management Consultants, Leusden.

Becker, J., en P. Dekker, (2005), Beeld van beleid en politiek, in: Sociaal en Cultureel Planbureau, De sociale staat van Nederland 2005, Den Haag, Sociaal en Cultureel Planbureau.

Bogt, H.J. ter (2003), Performance evaluation styles in governmental organizations, Management Accounting Research, Vol. 14, No. 4, pp. 311-332.

Bogt, H.J. ter (2004), Politicians in search of performance information?, Financial Accountability \& Management, Vol. 20, No. 3, pp. 221-252.

Bogt, H.J. ter, (2005a), Financieel management bij woningcorporaties: van boekhouding naar beleid, Maandblad voor Accountancy en Bedrijfseconomie, jrg. 79, nr. 3, pp. 60-69.

Bogt, H.J. ter, (2005b), Managementvernieuwingen bij de overheid: mooie woorden of echte daden?, Zorg, Groningen.

Bordewijk, P., en H.L. Klaassen, (2000), Wij laten ons niet kennen, VNG Uitgeverij, Den Haag.

DiMaggio, P.J., en W.W. Powell, (1983), The Iron Cage Revisited: Institutional Isomorphism and Collective Rationality in Organizational Fields, American Sociological Review, Vol. 48, No. 2, pp. 147-160. 
English, L.M., J. Guthrie en L.D. Parker, (2005), Recent Public Sector Financial Management Change in Australia, in: J. Guthrie, C. Humphrey, L.R. Jones en O. Olson (red.), International Public Financial Management Reform - Progress, Contradictions and Challenges, Information Age Publishing, Greenwich, pp. 23-54.

Gow, J.I. en C. Dufour (2000), Is the new public management a paradigm? Does it matter?, International Review of Administrative Sciences, Vol. 66 , No. 4, pp. 573-597.

Helden, G.J. van, (1998), BBI in de praktijk, Shaker, Maastricht.

Helden, G.J. van en J. Bonhof, (1995), BBI en normen en kengetallen voor gemeenten, Stichting BBI, Leusden.

Helden, G.J. van, (1999), Planning en control bij de provincies, Openbare Uitgaven, jrg. 31, nr. 5, pp. 246-255.

Helden, G. J. van, en Å. Johnsen, (2002), A Comparative Analysis of the Development of Performance-based Management Systems in Dutch and Norwegian Local Government, International Public Management Journal, Vol. 5, No. 1, pp. 75-95.

Hood, C., (1991), A Public Management for All Seasons, Public Administration, Vol.69, No.1(Spring), pp. 93-109.

Hood, C., (1995), The "New Public Management" in the 1980s: variations on a theme, Accounting, Organizations and Society, Vol.20, No.2/3, pp. 93-109.

Houwaart, D. (red.), (1995), Van Beleids-en BeheersInstrumentarium naar Bestuurlijke vernieuwing Bedrijfsvoering en Informatie, Stichting BBI, Leusden.

InAxis (Ministerie van BZK) / Commissie Innovatie Openbaar Bestuur, (2004), Handboek Innovatiemonitor Openbaar Bestuur, InAxis, Den Haag. Jansen, E.P., (2000), Use, Needs and Determinants of Performance Information: Case Studies in Local Social Security Departments, Labyrint, Capelle aan den IJssel.

Kickert, W.J.M., (2000), Public Management Reforms in The Netherlands, Eburon, Delft.

Martens, M., K.J. Groen en B. van der Wal, (2002), Publiek Management - 65 modellen, FC Klap/Berenschot, Hilversum.

Meyer, J.W., en B. Rowan, (1977), Institutionalized Organizations: Formal Structure as Myth and Ceremony, American Journal of Sociology, Vol. 83, No. 2, pp. 340-363.

Ministerie van BZK - Binnenlandse Zaken en Koninkrijksrelaties, (2004), Kerngegevens Overheidspersoneel 2003, Ministerie van BZK, Den Haag.

Moret Ernst \& Young/Stichting A+O fonds Gemeenten, (1997), Tien Jaar Kwaliteitsverbetering bij Gemeenten, Stichting Arbeidsmarkt- en Opleidingsfonds Gemeenten, Den Haag.

Scapens, R.W., (2004), Doing case study research, in: C. Humphrey en B. Lee (red.), The real life guide to accounting research, Elsevier, Oxford, pp. 257-279.

Scapens, R.W., (1994), Never Mind the Gap: Towards an Instituional Perspective on Management Accounting Practices, Management Accounting Research, Vol. 5, No. 3/4, pp. 301-321.

Seal, W., (1999), Accounting and Competitive Tendering in UK Local Government: An Institutionalist Interpretation of the New Public Management, Financial Accountability \& Management, Vol.15, No.3/4, pp.309-327.

Shields, M.D., en S.M. Young, (1989), A Behavioral Model for Implementing Cost Management Systems, Journal of Cost Management, Vol. 3, No. 4, pp. 17-27.

\section{Noten}

1 In dit artikel wordt 'verandering' veelal aangeduid met 'vernieuwing', omdat de betrokken organisaties vaak dit woord hanteren (wellicht omdat het begrip vernieuwing naar het oordeel van betrokkenen een 'positieve bijklank' heeft en eerder de indruk wekt te leiden tot 'verbeteringen', dan het meer neutrale begrip verandering). De term organisatieverandering of -vernieuwing zou strikt genomen gereserveerd kunnen worden voor bijvoorbeeld veranderingen in de organisatiestructuur, producten of het gehanteerde 'technische' instrumentarium. DiMaggio en Powell (1983, p. 147) wijzen in dit verband evenwel ook op veranderingen in de organisatiecultuur. In dit artikel worden organisatieveranderingen of -vernieuwingen dan ook gevat onder het begrip managementverandering of -vernieuwing (dat dus zowel veranderingen in de organisatiestructuur en producten kan omvatten, als veranderingen in bijvoorbeeld de in organisaties gehanteerde accountinginstrumenten en managementmethoden en de organisatiecultuur).

2 De in het onderzoek betrokken gemeenten zijn Assen, Den Haag, Eindhoven, Groningen, Hengelo (O), Hoogezand-Sappemeer, Leeuwarden, Nijmegen, Rotterdam, Smallingerland, Utrecht en Zwolle. De erin betrokken provincies zijn Fryslân en Groningen. Zie voor een uitgebreid onderzoeksverslag Ter Bogt, 2005b.

3 De start van met BBI verwante initiatieven, zoals het 'Tilburgse model' en vergelijkbare ontwikkelingen in bijvoorbeeld Delft en Groningen, lag rond 1985 (zie bijvoorbeeld Kickert, 2000). Pas met een artikel dat Hood in 1991 publiceerde, werd de term New Public Management een standaardaanduiding voor allerhande vernieuwingen in het management van de overheid die internationaal en in Nederland de ronde deden (Hood, 1991).

4 Terzijde kan worden opgemerkt dat wellicht in de praktijk van profiten non-profitorganisaties geen sprake is van sturing op met name, of uitsluitend, de outputs. Misschien wordt veeleer gestuurd op inputs, proces/throughputs én outputs (zie Ter Bogt, 2003, p. 325-328). Echter, BBI en NPM benadrukken vooral de wenselijkheid van (meer) sturing op outputs, in plaats van de 'traditionele' sturing van overheidsorganisaties die, mede in aansluiting op de principes van Weber, sterk was gericht op de inputs en de processen. Zie Gow en Dufour (2000) voor een meer principiële discussie van de verschillen en overeenkomsten tussen NPM en de op de denkbeelden van Weber gebaseerde overheidsbureaucratie.

5 Om misverstanden te vermijden, moet erop worden gewezen dat niet vaststaat in hoeverre aan de profitsector ontleende instrumenten en managementmethoden zonder meer op een verantwoorde manier toepasbaar zijn in de overheidssector. In de overheidssector speelt bijvoorbeeld het winststreven in het algemeen een veel minder belangrijke rol dan in de profitsector, terwijl aspecten als rechtsgelijkheid en rechtmatigheid er vaak juist extra belangrijk zijn. Verder wordt het dikwijls moeilijker geacht om de overheidsprestaties op een enigszins volledige wijze te meten (zie ook Ter Bogt, 2004, p. 224). Mede hierom zijn diverse auteurs kritisch over de bedrijfsmatige aanpak die NPM voorstaat voor de overheidssector (zie bijvoorbeeld English et al., 2005).

6 Omnibusonderzoek houdt in principe in dat in een onderzoek meerdere onderwerpen aan de orde komen. De via een omnibus- 
onderzoek onderzochte onderwerpen kunnen van keer tot keer variëren. Een monitoronderzoek is een min of meer regelmatig herhaald onderzoek waarin in principe steeds dezelfde onderwerpen op dezelfde manier aan de orde komen. Zo kan een systematisch opgebouwd beeld worden verkregen van de ontwikkelingen in denkbeelden of oordelen over bepaalde onderwerpen in de loop der tijd. Soms wordt gewerkt met een combinatie van beide vormen van onderzoek (dus deels terugkerende en deels eenmalige vragen). Beide vormen van onderzoek zijn in het algemeen grootschalig en kwantitatief van aard en kunnen schriftelijk, telefonisch, 'face-to-face' of via internet worden uitgevoerd.

7 Ruw samengevat, waren van de 23 geïnterviewden er 21 van mening dat 'zakelijke' overwegingen in meerdere of mindere mate een aanzienlijke rol speelden bij het doorvoeren van de managementvernieuwingen. Uit de antwoorden van twee personen valt af te leiden dat zij van oordeel waren dat dit misschien in beperkte mate het geval was. Van het volgen (en leren) van ontwikkelingen elders, trends en dergelijke, was volgens veertien geïnterviewden sprake, terwijl vier personen stelden dat ontwikkelingen elders mogelijkerwijs van invloed waren. Volgens één persoon speelden ontwikkelingen elders geen rol; vier personen lieten zich er niet over uit.

8 Zie in dit verband bijvoorbeeld ook de Innovatiemonitor Openbaar bestuur, die door Andersson Elffers Felix en Stichting Rekenschap werd ontwikkeld in opdracht van InAxis (Commissie Innovatie Openbaar Bestuur) en in samenwerking met de gemeentesecretarissen van gemeenten met 100.000 of meer inwoners. Het Handboek Innovatiemonitor Openbaar Bestuur (InAxis, 2004) bevat diverse voorbeelden van in grotere gemeenten verzamelde prestatiegegevens over het functioneren van het ambtelijk apparaat.

9 Wederom zeer ruw samengevat, gaven van de 23 geïnterviewden er 15 aan dat per saldo in meerdere of mindere mate verbetering optrad in zaken als het financieel beheer, het zakelijk en/of efficiënt functioneren van de organisatie, de kwaliteit van de dienstverlening, of het realiseren van de beleidsdoelen. Uit de antwoorden van de overige acht geïnterviewden kan worden geconcludeerd dat zij van oordeel waren dat zich misschien op dergelijke aspecten (zeer) lichte verbeteringen voordeden.

10 Enkele geïnterviewden gaven aan dat als geldt dat burgers stilzwijgend in de loop der tijd betere prestaties verwachten van de overheid, net zoals zij dat vaak doen bij profitorganisaties, het op niveau blijven van de 'klanttevredenheid' misschien mag worden gezien als een teken dat de kwaliteit van de dienstverlening in 'absolute zin' iets verbeterde. 